\title{
“ZIKIR GEMILANG" ELITE POLITIK DI BANDA ACEH: Wacana Populis atau Kebijakan Publik?
}

\author{
Saiful Akmal, Rizkika Lhena Dharwin, dan Siti Nur Zalikha \\ Universitas Islam Negeri Ar-Raniry, Banda Aceh, Indonesia \\ E-mail: saiful.akmal@ar-raniry.ac.id ; rizkikadarwin@ar-raniry.ac.id ; \\ sitinurzalikha@ar-raniry.ac.id
}

\begin{abstract}
ABSTRAK. Zikir publik menjadi arus baru di Aceh setelah tsunami. Dalam perkembangannya, zikir digunakan oleh elit politik baik ketika pilkada sebagai strategi kampanye, maupun sebagai kebijakan populis dalam menjalankan pemerintahan. Begitu pula Pemerintah Kota Banda Aceh periode 2017-2022 yang menjadikan zikir sebagai salah satu program utama yang kemudian diberi nama "zikir gemilang". Penelitian ini tertarik untuk melihat implementasi zikir ini apakah cenderung sebagai wacana populis atau kebijakan publik. Penelitian ini menggunakan pendekatan kualitatif lewat metode wawancara semi struktur dan bola salju terhadap sejumlah informan kunci. Hasil penelitian ini menunjukkan bahwa meskipun pemahaman ulang terhadap fenomena zikir dari wacana ke aksi terjadi, namun itu sebatas pergantian slogan dari "madani" ke "gemilang". Kemudian, ada tiga dimensi wacana dominan yang dimainkan oleh elit terkait pelaksanaan kebijakan zikir: 1) wacana dimensi sosial budaya (islam sebagai sistem sosial), 2) wacana dimensi ekonomi (wisata islami) dan 3) wacana dimensi politik (kebijakan populis demi elektabilitas). Penelitian ini juga mengindikasikan bahwa program zikir cenderung menjadi wacana populis untuk membentuk citra elit. Dengan demikian, kebijakan zikir digunakan sebagai pemenuhan janji kampanye, dan sarana komunikasi atau klarifikasi publik terhadap kebijakan-kebijakan yang dibuat oleh pemerintah.
\end{abstract}

Kata kunci: elit politik; "zikir gemilang"; wacana populis; kebijakan publik

\section{“GLORIOUS DHIKR" OF POLITICAL ELLITE IN BANDA ACEH: Populist Discouse or Public Policy?}

\begin{abstract}
Remembrance to God (dhikr) in public has become a new trend in Aceh after the tsunami. Ever since, dhikr is used by political elites both as electioneering strategy during the political campaign, and as a populist discourse and policy in running the government. Likewise, the elected mayor of Banda Aceh for 20172022 administration introduced dhikr as one of their priority program to support the Islamic tourism, later named "Zikir Gemilang". They formalized the rituals, thus allocated state funds to finance the activities. Therefore, this study is interested in scrutinizing the implementation of this dhikr as a populist discourse or public policy. Qualitative approach is used by using semi-structured and snowball interview techniques with key informants. The results of this study indicates although the process of redefining dhikr is taking place in Banda Aceh in terms of moving on from discourse into action, it is still substanstially limited to the change of slogan from "madani" (civilized), to "gemilang" (glorious). In terms of its dominant discourses played by the ellites in the context of dhikr implementation, this study has found at least three major discourses: 1) socio-cultural discourses (Islam as a social system), 2) economic discourse (Islamic tourism), and 3) political discourse (populist policy toward electability). As a result, this study unlock the fact that dhikr has been excercised to discursively promote populist policy as a mean of faih securitization, political compensation, political communication, and public aspirations.
\end{abstract}

Key words: political ellite; "glorius dhikr"; populist discourse; public policy

\section{PENDAHULUAN}

Zikirmerupakan ibadah komunal yang mulai berkembang diAceh pasca tsunami, tepatnya pada 2007 dan hadir sebagai ritual kolektif di ruang publik. Sebelumnya, zikir adalah ibadah personal dan berkelompok yang biasa terbatas pada tarekat tertentu (Fikri, 2014). Saat ini kehadiran zikir di ranah publik dilakukansecara terbuka dan umumnya menambahkan kata 'akbar', yang merujuk pada kegiatan massal yang melibatkan banyak orang dengan harapan untuk perbaikan sikap masyarakat (Maulana, 2017); fenomena religiusitas gaya baru dengan kemunculan majeliz zikir sebagai bagian ritual keislaman (Zamhari, 2007) dan bentuk-bentuk sufisme baru kelas menengah perkotaan adalah program-program keagaamaan seperti kursus-kursus tasawuf, seminar-seminar seputar spiritualitas, program televisi dan zikir (Ardiyaningrum, 2017). 
Tren zikir sudah mulai dimanfaatkan oleh elit politik sebagai media berkomunikasi dengan publik, baik ketika masa kampanye maupun ketika memasuki fase kepemimpinannya. Zikir, yang tadinya menjadi simbol kesalehan pribadi, saat ini menjadi bagian dari negosiasi (termasuk politik) di ruang publik (Hasan, 2012). Begitu pula dalam konteks lokal di Aceh. Zikir menjadi manifestasi wujud tasawuf yang merambah ruang publik di era syariat (Shadiqin, 2018); dan sebagai media kampanye yang dapat memobilisasi massa secara massif (Masrizal, 2017).

Penggunaan zikir sebagai media bukan hanya pada konteks Pemilu, namun juga berkesinambungan dengan setelah pemilu dalam bentuk kebijakan. Seperti pasangan AminullahZainal Arifin, kepala daerah di Kota Banda Aceh. Ia menggunakan zikir sebagai media kampanye Pilkada dan menjadi sebuah kebijakan ketika menjabat.

Melihat zikir digunakan untuk membentuk popularitas di masyarakat, sebagaimana berupaya membentuk populisme politisi. Wacana populisme muncul di Asia Tengagra pada krisi moneter 1997. Elit ambil bagian untuk mendominasi lewat keterbentukan figur pemimpin yang kuat, memiliki daya tarik karismatik, bukan berdasarkan program dan ideologis (Mudde \& Kaltwasser, 2017), yaitu menekankan pada kekuatan personal, yang bersifat top down dan pada realinya tanpa pengaruh ideologis tertentu. Begitu pula di Amerika Latin dan Eropa, populisme klasik bergerak karena lahirnya tokoh akibat terjadinya pembusukan negara secara umum yang dianggap salah urus, korupsi. Hal ini bisa dilihat ketika wacana populisme di Amerika Latin oleh Hugo Chavez di Venezuela (Hawkins, 2009), Alexis Tsipras di Yunani yang cenderung berideologi sayap kiri radikal. Mereka umumnya mengedepankan wacana anti liberalisme dan populer pada masa paska perang dingin. Ini merupakan lanjutan dari konflik ideologi liberal dimana Amerika Serikat dan sekutunya menjadi pengusung utama melawan ideologi komunis, sosialis yang diusung oleh Rusia, Kuba dan China. Disisi lain, Timur Tengah juga mempraktikkan populisme, ketika stabilitas geopolitik yang lemah (Perang Syria, Libia, Iraq), kelompok politik sayap kanan kembali mendapatkan angin segar di situasi poskomunis Barat (Hanley, 2004; Fennema, 2005) dan juga seiring dengan kemenangan Donald
Trump di pemilihan Presiden Amerika Serikat (Pierson, 2017).

Begitu pula Eropa Barat, wacana rasispopulisme yang fokus pada penolakan imigran muslim, kontra regionalisme dan anti Uni Eropa mereka (Ivarsflaten, 2008). Wacana ini cukup efektif untuk memenangkan pemilihan dari sentimen wacana anti asing dan nasionalisme ras mereka. Di Italia ada Silvio Berlusconi dengan Forza Italia dan Matteo Salvini dengan Lega Nordnya (Ruzza \& Balbo, 2013; Albertazzi; Giovannini \& Seddone, 2018), di Perancis ada Marie Le Pen dengan Populist Party dan Front National (Stockemer \& Barisione, 2017), di Hungaria ada Viktor Orban dengan wacana nasionalisme Partai Fidesz (Ádám, 2019), di Belanda ada Geet Wilders dengan PVV (Partai Kebebasan) dan Thiery Baudet dengan partai Forum for Democracy (Faber, 2018), di Jerman ada Bernd Luecke dan kawan-kawan dengan partai Alternative for Germany atau AfD (Franzmann, 2016) dan di Inggris ada Nigel Farage dari UK Independence Party serta Perdana Menteri Boris Johnson dengan Partai Konservatif(Montgomerry, 2017).

Di Indonesia kondisinya sedikit berbeda, Mietzner(2015)menyebutnyasebagaipopulisme teknokratik, sementara Aspinall (2015) lebih suka dengan istilah populisme oligarki. Populisme teknokratik merujuk pada orientasi citra yang terbentuk fokus pada pemerintahan dan pelayanan publik, inklusif, dan nasionalis. Politikus menjadi semakin bergantung kepada populisme dan relasi kepemimpinan karismatik antara pemilih dan politikus (Acemoglu, Egorov, \& Sonin, 2013). Bahkan kampanye populisme kerap dilekatkan dengan kampanye negara kesejahteraan yang menghiasi nuansa politik lokal di Indonesia. Karena menekankan pada kekuatan komunitarian, populisme menjadi gerakan politik mayoritas (Laclau, 2005). Lambat laun, populisme yang pada awalnya memiliki esensi kesejahteraan bergeser kepada modus operandi kekuasaan (Pratikno \& Lay, 2011). Hal demikian menurut Kenny (2017), populisme dapat menjadi ancaman nyata bagi demokrasi, dan akan terus meningkat untuk masa yang akan datang dan Hadiz (2016) menjelaskan bahwa populisme Islam sebagai sebuah reaksi oleh kelompok tertentu khususnya terhadap marginalisasi politik dan ekonomi sebagai akibat kemajuan kapitalisme. Bila demikian, bisa jadi 
wacana agama digunakan sebagai wacana bersama untuk menarik rasa takut kolektif akan kejahatan sebagai isu populer (Chevigny, 2003), serta lebih umumnya sebagai cara untuk menarik perhatian publik. Dalam tulisan Knight $(1998,2011)$, ia menyebutnya dengan istilah neo-populisme, yaitu gaya politik elit dengan manipulasi yang dilakukan untuk membentuk definisi mentalitas wacana diskriminasi politik antara "kami dan mereka" (Wodak, 2008) atas nama "rakyat" (Chilton, 2017).

Dalam studi wacana politik kritis kontemporer di Indonesia, kebijakan publik sering dikaitkan dengan post-truth, media sosial dan misinformasi, khususnya ditengah pergulatan demokrasi (Jatmiko, 2019). Khusus dalam aspek relevansi praktik beragama dalam bingkai politik, Iqbal (2014) menyebutkan ada dinamika ketika formalisasi syariat Islam di beberapa daerah di Indonesiadalamperspektifrelevansinya terhadap kebijakan publik pemenang demokrasi. Dalam beberapa aspek misalkan, kebijakan publik, khususnya yang deliberatif, tantangannya adalah mengenai relevansi masih berputar-putar dalam ranah wacana akademik saja, sebagaimana yang dikemukakan oleh Mardiyanta (2011).

Fairclough (2013), menganggap studi wacana politik dalam ranah kebijakan publik keduanya harus menggunakan pendekatan analisis "kritis". Bahkan menurut Leifeld (2010), ada "rantai terputus" yang menghubungkan studi wacana kebijakan publik yang membutuhkan pendekatan analisa wacana politik berbasis jaringan (political discourse network). Leifeld (2013) juga menyebutkan bahwa pendekatan wacana politik jaringan bisa menjelaskan relasi konsep dalam konteks koalisi politik untuk menghasilkan sebuah kebijakan publik yang besar. Dalam bahasa lain, Gregory (2014) mengatakan bahwa studi wacana politik adalah upaya mengevaluasi praktik good governance dengan standar ilmiah yang ada.

Melihat literatur fenomena wacana populisme dalam konteks politik komporer Indonesia yang semakin berkembang, maka menarik untuk melihat kebijakan Zikir di Kota Banda Aceh pada tahun 2017 hingga 2019. Hal yang membedakan fokus kami dari kajian yang sebelumnya adalah kami mencoba mengurai apa motif elit dalam kebijakan zikir oleh kepada daerah di Kota Banda Aceh. Motif kebijakan "zikir gemilang" untuk membentuk wacana populis sehingga elit mendapatkan dukungan publik menjadi menarik untuk ditelaah dalam konteks Aceh yang memberlakukan formalisasi hukum Islam. Maka kebijakan tersebut menjadi pilihan rasional dalam skema kebijakan publik yang dipilih oleh elit, dan bukan semata praktik ritual keagamaan.

Untuk melihat hal tersebut, kami menggunakan teori pilihan rasional, dimana menunjukkan pilihan dalam menentukan kebijakan publik yang cenderung mendorong elit populis. Maksudnya adalah, konsep ini mempelajari perilaku elit di arena publik dan mengasumsikan bahwa individu mengejar gagasan mereka sendiri tentang kepentingan publik (Dye 2011).

Mereka memformulasikan posisi kebijakan mereka untuk memenangkan pemilihan; mereka tidak memenangkan pemilihan untuk memformulasikan kebijakan. Bukan sesuatu hal yang aneh bila wacana kampanye kandidat bersifat retorik dan naratif, sehingga masingmasing pihak dan kandidat mencari kebijakan yang bisa menarik jumlah pemilih yang besar. Maka, sebagai sebuah argumentasi akademik, tulisan ini diharapkan dapat menjelaskan apakah kebijakan zikir tersebut hanya sebatas wacana populis ketika kampanye dan apakah kebijakan itu adalah sebuah kebijakan politik yang fokus menyelesaikan masalah dan berdampak pada masyarakat dan tindakan politik para elitnya.

\section{METODE}

Creswell (2009) mengatakan bahwa rancangan penelitian berisikan rencana detil dan prosedur dalam pengumpulan dan analisis data. Ada dua alasan mengapa kemudian rancangan penelitian menjadi begitu penting. Pertama, rancangan penelitian akan membantu proses pengumpulan data di lapangan. Kedua, yang juga tidak kalah pentingnya adalah ia bisa membantu memastikan bahwa data bisa menjawab pertanyaan penelitian yang diajukan.

Dalam tulisan ini, kami menggunakan jenis penelitian kualitatif dengan pendekatan fenomenologis. Menurut Mason (2002), penelitian kualitatif membuat peneliti mampu melihat dimensi yang luas dari fenomena sosial, kehidupan, pengalaman dan juga hubungan diantaranya. Sehingga, pendekatan kualitatif bisa membuatmetodeyangmampumenyediakandata, 
membangun analisis serta mengkomunikasikan hasilnya kepada pembaca (Tracy, 2019).

Selain itu, pendekatan fenomenologis diharapkan bisa membantu menjelaskan fenomena baru yang berkembang di dalam salah satu atau sebagian elemen masyarakat seusai fenomena itu dipahami dan sesudah fenomena itu terjadi. Vagle (2018, p. 82) menyebutnya dengan istilah "post-reflexivity", dimana sebuah fenomena bisa secara reflektif dijelaskan dari pengalaman hidup partisipan. Pendekatan fenomenologis dalam studi kualitatif, meski terkadang memberikan pemahaman tunggal terhadap sebuah fenomena, namun ia bisa meningkatkan pemahaman terhadap sebuah kejadian serta memberikan perspektif alternatif terhadap sebuah pengalaman sosial (Astalin, 2013)

\section{Partisipan}

Lokasi penelitian ada di wilayah Kota Banda Aceh. Durasi penelitian ini adalah sekitar selama kurang lebih 4-5 bulan, dimulai sejak Bulan Juli sampai dengan Bulan Oktober 2019. Untuk itulah proses penemuan objek penelitian dilakukan dengan pendekatan teknik purposive sampling atau judgment sampling. Dalam teknik ini, partisipan atau informan kunci diseleksi secara terbatas sesuai relevansi informasi yang mereka punyai terkait riset. Tujuannya adalah menemukan informasi untuk menjelaskan fenomena yang ingin diungkap (Etikan, Musa \& Alkassim, 2016).

Data kemudian didapat melalui informan kunci dan sekunder dari masing-masing kegiatan zikir. Para informant mempunyai kemiripan karakter dan keterwakilan juga sesuai dengan relevansi peran mereka dalam kegiatan zikir baik langsung maupun tidak langsung di lingkup kota Banda Aceh. Mereka yang menjadi informan kunci dan terlibat langsung adalah: Pengelola Majelis Zikir dan Pengajian Gemilang, Panitia Penyelenggara Zikir, Dinas Syariat Islam, Masyarakat Peserta Zikir, Ustad dan Penceramah. Sementara informan sekunder yang tidak terlibat langsung adalah Konsultan Politik Walikota Banda Aceh, Bagian Perizinan Polresta Banda Aceh, Tokoh Ormas Keagamaan, Dinas Pariwisata Kota Banda Aceh.

\section{Pengumpulan Data}

Untukmenjawabpertanyaandalampenelitian ini, kami menggunakan metode wawancara semi- struktur sebagai alat pengumpulan data. Fontana dan Frey (2000) mengatakan bahwa model ini "sangat membantu sekali dalam memahami sebuah fenomena kemanusiaan yang terjadi".

Disini partisipan bisa memberikan tanggapan dan pemikiran mereka secara maksimal. Lebih jauh lagi, menurut Flick (2018) ia percaya bahwa "narasi-narasi bisa dikumpulkan dan dianalisa kemudian, atau diproduksi dalam bentuk bentuk khusus melalui wawancara". Ada kalanya juga menggunakan teknik wawancara kombinasi seperti halnya, wawancara bola salju (snowball) dimana satu narasumber bisa merekomendasikan calon narasumber lain jika dianggap relevan.

\section{Analisa Data}

Penelitian ini memakai model analisa data tematik reflektif. Tujuannya adalah agar analisa datamampumemberikanruangbagicarapandang, interpretasi partisipan dalam konteks penelitian (Guest, MacQueen \& Namey, 2012). Data-data yang dikumpulkan melalui wawancara kemudian akan ditanskripsikan dan dipilah sebagai data yang relevan informasinya. Kemudian ia akan diseleksi dan dikategorisasi yang bisa dianalisis dengan menggunakan open coding (Corbin \& Straus, 2018). Maksudnya adalah, data-data yang diseleksi itu kemudian akan menjadi tema-tema penting yang didapat melalui "pengulangan, persamaan, perbedaan dan kategori atau tipologi yang khas" (Silverman, 2016).

Model triangulasi sumber melalui wawancara disini digunakan sebagai upaya validasi dalam penelitian kualitatif (Flick, 2011). Teknik pengolahan data secara kualitatif melalui tiga tahap menurut Huberman \& Miles, 2002). Pertama, Reduksi Data dengan menggolongkan, mengarahkan, dan membuang data yang tidak perlu dan mengorganisasikan data sedemikian rupa sehingga dapat ditarik kesimpulan akhir. Kedua, Penyajian Data yang dilakukan untuk menemukan pola-pola disusun secara sistematis untuk mengambil kesimpulan serta memberikan tindakan. Data-data berwujud angka, kata-kata, kalimat atau paragraph, akan disajikan dalam bentuk teks atau uraian naratif. Ketiga, Penarikan Kesimpulan adalah dimana hasil analisis data digunakan untuk menarik kesimpulan final yang menggambarkan pola umum dari peristiwa-peristiwa dan berusaha memberikan rekomendasi. 


\section{HASIL DAN PEMBAHASAN}

\section{Zikir Gemilang: Dari Aktivitas Reliji menjadi Kebijakan Publik di Banda Aceh}

Untuk memberikan gambaran umum terkait proses bagaimana zikir bertransformasi dari kegiatan reliji menjadi bagian dari kebijakan publik, penjelasan dibawah diharapkan bisa memberikan peahaman awal kontekstual dalam studi ini. Saat ini, aktifitas zikir dengan mudah ditemukan di Aceh secara umum dan Banda Aceh secara khusus dalam berbagai kegiatan yang diselenggarakan oleh masyarakat dan bahkan juga oleh pemerintah setempat, baik level propinsi maupun kabupaten/kota. Usai konflik dan tsunami, masyarakat Aceh larut dalam zikir akbar yang diselenggarakan pemerintah untuk memperingati rasa kesyukuran kolosal, minimal pada tanggal 15 Agustus (perjanjian Helsinki) dan 24Desember (peristiwa tsunami) di pelataran masjid-masjid raya propinsi, kabupaten kota dan kecamatan. Kegiatan ini menjadi semakin populer karena ditayangkan secara langsung di televisi lokal maupun nasional, disiarkan secara reguler oleh radio dan diberitakan secara masif di surat kabar lokal dan nasional.

Dalam satu dekade terakhir, Banda Aceh juga mengalami hal tersebut. Tsunami adalah titik tolak gerakan zikir di Aceh. Secara signifikan, demikian juga halnya di Banda Aceh, karena ia adalah ibukota propinsi, maka kesemua hal terkait kebijakan populer zikir akbar tentunya juga tidak mengherankan jika dimulai dan dijadikan contoh bagi daerah lain di propinsi Aceh.

Pada periode pemerintahan Walikota wanita Iliza Saadudin Jamal yang melanjutkan kepemimpinan alm. Mawardi Ismail, Banda Aceh Kota Madani yang menjadi kampanye benar-benar memberi ruang yang cukup bagi kelompok-kelompok muslim untuk berekspresi. Misalnya saja, beliau membuat mimbar Jumat yang kemudian mengundang para dai kondang nasional seperti Yusuf Mansyur, Arifin Ilham, Peggy Melati Sukma dan lain sebagainya. Kegiatan ini dilakukan di Taman Sari Kota Banda Aceh yang pada masa beliau berganti nama menjadi Taman Bustanus Salatin. Inilah yang mungkin dimaksud oleh Shadiqin (2018) sebagai tarekat urban yang mengedepankan "sisi lain" dari cara beragama dalam masyarakat kota dan "tasawuf modern" atau "neo-sufism", meski majeliz zikir tertentu mempunyai afiliasi dengan gerakan tarekat yang duluan ada di dunia.

Setelah kepemimpinan Mawardi dan Illiza berakhir, trend kegiatan zikir masih juga berlanjut oleh masa kepemimpinan Aminullah Usman dan Zainal Arifin, yaitu Walikota dan Wakil Walikota Banda Aceh hasil Pilkada Kota Banda Aceh 2017. Bahkan setelah memenangkan Pilkada dan ditetapkan sebagai walikota, mereka melahirkan kebijakan untuk mewujudkan Banda Aceh sebagai kota zikir sebagai salah satu realisasi janji kampanyenya. Bahkan ketika terpilih menjadi Walikota Banda Aceh periode 2017-2022 ${ }^{1}$, menjadikan kebijakan zikir sebagai salah satu kebijakannya. Aminullah meluncurkan Majelis Zikir dan Pengajian Gemilang (selanjutnya disebut MPG) pada September 2017 (Humas Pemko Banda Aceh, 2018). Program tersebut bertujuan menjadikan Banda Aceh sebagai kota zikir sehingga mendukung penerapan Syariat Islam². Zikir dilakukan setiap kamis malam di Pendopo Walikota Banda Aceh. Kegiatan yang menyerap anggaran sebesar Rp 10.000.000/ kegiatan tersebut sifatnya wajib bagi PNS serta seluruh staf di jajaran Pemerintah Kota Banda Aceh. Namun bagi masyarakat, keikutsertaan dalam kegiatan ini masih bersifat himbauan. Kegiatan zikir rutin ini disebut sebagai Zikir Gemilang.

Selain zikir secara rutin, beberapa momen memperingati hari besar juga diperingati dengan menyelenggarakan zikir. Misalnya saja HUT Kota Banda Aceh ke 813 tahun, dimana peringatannya diperingati dengan zikir di Blang Padang Kota Banda Aceh pada 20 April 2018. Demikian pula untuk memperingati hari besar lainnya seperti Tahun Baru Hijriah Islam 1 Muharram (Yulianto, 2018).

\section{Zikir sebagai Kebijakan Populis: Menelusuri Motif Elit dan Dampaknya}

Zikir Gemilang menjadi sebuah kebijakan publik, karena aktivitas dan pelaksanaannya menggunakan APBK Kota Banda Aceh (dana publik) dan diperuntukkan bagi publik. Selain itu, dalam pelaksanaannya berkaitan erat dengan cara pemerintah menjadikannya fasilitas yang memediasi pemerintah dengan masyarakat Kota

\footnotetext{
1 Admin Nba. (2018, 12 September). Wujudkan Kota Zikir, Wakil Wali Kota: Kami Sangat Berharap Doa Dari Kita Semua. News Banda Aceh. Diakses Dari Http:// Newsbandaaceh.Com/

2 Junaidi, H. (2018, 28 April), Diakses dari https://bandaacehkota. go.id/berita/9483/pendopo-selalu-dipenuhi-jemaah-zikiraminullah-saya-sangat-bahagia.html
} 
Banda Aceh. Maka seberapa jauh kebijakan ini berdampak pada kepentingan publik menjadi penting sebagai dasar melihat motif elit dalam kebijakan tersebut. Zikir, bila menjadi sebuah kebijakan dan difasilitasi oleh negara, berarti memiliki beberapa motif elit dalam perencanaan kebijakan. Dalam hal ini akan dikategorikan dalam beberapa dimensi, yaitu:

\section{Dimensi Wacana Sosial Budaya: Agama Sistem Sosial Masyarakat Banda Aceh}

Dimensi sosial budaya pada kebijakan zikir diwacanakan sebagai sistem sosial yang sesuai bagi masyarakat Banda Aceh. Pemko Banda Aceh memiliki visi "Terwujudnya Kota Banda Aceh Gemilang Dalam Bingkai Syariah". Gemilang adalah menjadikan Kota Banda Aceh yang termasyhur dan terpandang dalam tiga pilar utama, yaitu agama, ekonomi dan pendidikan, menuju kejayaan dengan memperhatikan keadilan gender. Sedangkan Bingkai Syariah adalah mendasarkan seluruh proses penyelenggaraan pemerintahan, pelaksanaan pembangunan dan kehidupan sosial kemasyarakatan sesuai dengan Syariat Islam. Untuk mewujudkan visi tersebut, terdapat tujuh misi ${ }^{3}$ yang dilakukan, salah satunya adalah meningkatkan pelaksanaan Syariat Islam dalam bidang penguatan aqidah, syariah dan akhlak. Hal Ini untuk memastikan bahwa penyelenggaraan pemerintahan, pelaksanaan pembangunan dan pembinaan sosial kemasyarakatan benar-benar berada dalam bingkai syariat Islam secara kaffah.

Zikir menjadi kebijakan populis yang dilakukan oleh Pemerintah Kota Banda Aceh untuk membentuk aqidah, syariah dan akhlak, agar terwujudnya pelaksanaan syariat Islam secara kaffah (sempurna). Kebijakan populis ini mendapatkan penerimaan karena Aceh sangat kuat dengan narasi agama dan pelaksanaan Syariat Islamnya. Walaupun kebijakan ini sangat populer di wilayah urban lain di Aceh seperti Kota Langsa, Kota Meulaboh, Kota Banda Aceh dan sebagainya.

Bila menilik sejarah Aceh, pada dasarnya zikir sudah lama dipraktikkan oleh masyarakat

3 Misi Kota Banda Aceh, diantaranya: 1. Meningkatkan pelaksanaan Syariat Islam dalam bidang penguatan aqidah, syariah, dan akhlak. 2. Meningkatkan kualitas pendidikan, kebudayaan, kepemudaan, dan olahraga. 3. Meningkatkan pertumbuhan ekonomi, pariwisata, dan kesejahteraan masyarakat. 4. Meningkatkan kualitas kesehatan masyarakat

5. Meningkatkan kualitas tata kelola pemerintahan yang baik. 6 . Membangun infrastruktur kota yang ramah lingkungan dan berkelanjutan. 7. Memperkuat upaya pemberdayaan perempuan dan perlindungan anak.
Aceh sebagai sebuah ritual beribadah. Poin utama dari zikir adalah kedekatan umat dengan Allah SWT. Agama di Aceh menjadi sistem sosial yang diajukan pedoman dan acuan dalam menjalani kehidupan. Ketaatan dan kedekatan dengan Allah SWT dianggap oleh pemerintah dapat menjadi sistem dan tatanan sosial yang berdampak pada keamanan dan kenyamanan di masyarakat.

Tim Aminullah Usman dan Zainal Arifin mengklaim bahwa Walikota terdahulu dalam hal penegakan Syariat Islam sangat fokus dengan penindakan, bukan pencegahan secara substantif. Maka mereka melihat zikir sebagai kebijakan strategis untuk menciptakan pencegahan secara substantif yang berdampak pada keamanan dan kenyamanan di lingkungan sosial masyarakat. Berikut keterangan dari tim konsultan beliau:

Pemenuhan hak dasar itu penting, namun penegakan Syariat Islam juga penting. Namun sebelum Pak Amin dalam hal penegakan Syariat Islam (lebih) tertuju pada penindakan, sedangkan kita lebih pada pencegahan, jadi lebih substantif, salah satunya zikir. (RJ/ 4 Juli 2019).

Tujuan pencegahan terhadap pelanggaran syariat dalam tatanan masyarakat, maka data Mahkamah Syariat menjelaskan hal berbeda. Namun menurut data dari Mahkamah Syariah, pelanggar qanun Jinayat semakin meningkat dari tahun 2017 sampai dengan tahun 2019. Pada tahun 2017 kasus yang diterima oleh Mahkamah Syariah sebanyak 32 kasus, menurun sedikit menjadi 31 kasus pada tahun 2018, dan semakin meningkat menjadi 60 kasus pada tahun 2019.

Dapat dikatakan bahwa kebijakan zikir belum efektifmenjadi mainstream approach bagi warga sebagai wujud konsistensi pemerintah dalam mendukung penerapan syariat Islam. Peningkatan kasus pelanggaran syariat Islam dalam jumlah hampir dua kali lipat dari tahun 2017 mengkonfirmasi ketidakefektifan wacana sosial budaya berbasis religius oleh Pemko Banda Aceh. Penegakan syariat Islam lebih kepada wacana politik, dan belum menyentuh esensi keinginan publik, apalagi pencegahan sebagaimana yang dikemukakan informan diatas. Agama dieksploitasi sebagai wacana politik pembeda dengan kandidat petahana. Homo economicus dalam pilihan publik untuk kepentingan politik temporer sangat terasa pada dimensi sosial budaya, sementara nuansa homo politicus semakin berubah pada tataran konsep 
dan praktik menjadi kian negatif. Akhirnya, pilihan publik menjadi pilihan pribadi dan kelompok (Benington, 2011).

Demikian juga jika ditilik dari aspek wacana politik kritis, penggunaan isu sosial budaya, khususnya wacana agama sebagaimana yang dilakukan Pemko Banda Aceh bisa menjadi sentimen krusial. Dalam situasi paska sekularisme (Wilson, 2012), posisi agama dalam politik global, nasional dan lokal menjadi sedemikian signifikan.

\section{Dimensi Wacana Ekonomi: Sebagai Model Wisata Islami}

Elit Kota Banda Aceh merumuskan zikir sebagai sebuah kebijakan bertujuanuntukmenuju model wisata Islami. Mereka ingin menjadi role model wisata halal dan mendatangkan keuntungan ekonomi dan peningkatan kesejahteraan masyarakat. Seperti yang dijelaskan pada pembahasan pertama, zikir yang dipraktikkan dahulu di Aceh, tidak melibatkan negara secara formal, terutama didukung secara kebijakan (himbauan) pemerintah dan anggaran. Namun zikir yang dipraktikkan saat ini dilakukan oleh pemerintah (baca: negara), di publikasi secara luas, memobilisasi peserta melalui perangkat negara, dilaksanakan oleh perangkat negara serta dianggarkan oleh anggaran negara. Dapat dikatakan zikir yang dipraktikkan menjadi sebuah produk kebijakan formal. Sehingga praktik zikir yang dilaksanakan oleh pemerintah Kota Banda Aceh bukan sekedar ritual ibadah sebagaimana yang disampaikan dalam tinjauan sejarah di atas. Alasannya karena zikir adalah salah satu kebijakan unggulan Pemerintah Kota Banda Aceh.

Melihat proses tersebut, zikir ini dipublikasi agar menarik perhatian publik, bukan saja lokal, namun juga nasional dan internasional. Publikasi secara meluas, termasuk dengan rencana pembangunan pusat zikir di Ulee Lheu bertujuan untuk menarik wisatawan. Zikir rutin setiap Minggu bertujuan untuk membangun dukungan menuju Banda Aceh sebagai Kota Zikir. Berikut penjelasan Dinas Pariwisata:

Dengan kegiatan-kegiatan islam ini terus kita kembangkan ya, baik zikir, dakwah ya, kemudian hal-hal lainnya ya yang menyangkut dengan masalah keagaman ini tetap terus dikembangkan, ... kita ingin Banda Aceh ini menjadi destinasi wisata halal (IS/ 10 Juli 2019).
Maka data wisatawan dapat diajukan acuan. Dimana data menunjukkan bahwa rata-rata lama menginap tamu asing lebih tinggi dibanding ratarata lama menginap tamu nusantara baik untuk hotel bintang maupun akomodasi lainnya. Pada tahun 2018, Dinas Pariwisata mencatat rata-rata lama menginap tamu asing untuk hotel bintang dan akomodasi lainnya masing-masing sebesar 3,57 hari dan 3,84 hari, sedangkan rata-rata lama menginap tamu nusantara untuk hotel bintang akomodasi lainnya masing-masing selama 1,69 hari dan 2,12 hari.

Berdasarkan data tersebut, prediksi adanya peningkatan yang terjadi akibat adanya fenomena zikir untuk sementara ini dapat terbukti walaupun tidak signifikan. Secara komperehensif jika dari aspek ekonomi kegiatan zikir ini belum memberikan dampak sistematis terkait meningkatnya gairah dan pendapatan masyarakat di bidang ekonomi. Sejalan dengan pernyataan yang disampaikan oleh Kepala Dinas Pariwisata Kota Banda Aceh, bahwa sebenarnya minim peran dalam konteks zikir untuk memajukan ekonomi dan budaya.

Dalam aspek pilihan publik, wacana dan kebijakan Banda Aceh sebagai model wisata Islami sebenarnya sudah memberi dampak pada peningkatan aktivitas ekonomi publik. Pilihan publik dalam homo economicus menjadi pilihan rasional dalam konteks pengembangan kebijakan publik berbasis ekonomi islam dan wisata Islami. Hanya saja keseriusan pengelolaannya masih menjadi tanda tanya. Proses pengambilan kebijakan publik terkait penyediaan informasi baseline, alternatif opsi masih harus terus didorong untuk menjadi fokus utama Pemko, sebagaimana pengalaman Turki dalam mengelola destinasi wisata (Duman, 2011).

Disisi lain, penerapan model ekonomi wisata Islami, secara analisa wacana politik kritis, bisa dibaca sebagai bagian dari self-orientalism (Feighery, 2012), atau konstruksi ideologi (Neveu, 2010). Jika analisis ini relevan, maka bisa dikatakan Pemko Banda Aceh masih berada pada tataran penerapan konstruksi ideologi dalam masih pada tahap awal sekali dalam proses menilai kelebihan dan kekurangan serta kecocokan pasar.

\section{Dimensi Wacana Politik: Kebijakan Populis Demi Elektabilitas Publik}

Zikir dapat dilihat sebagai kebijakan populis yang dirumuskan oleh elit untuk 
meningkatkan elektabilitas. Kebijakan populis dalam perkembangannya sangat mendukung untuk membentuk figur dan karisma elit agar meningkatkan elektabilitasnya. Berikut beberapa poin yang dapat dijelaskan pada pelaksanaan kebijakan zikir

\section{1) Kebijakan zikir sebagai Simbol Keimanan atau Sekuritisasi Iman?}

Pasca reformasi isu agama meningkat di Indonesia. Bahkan isu agama menjadi landasan beberapa kebijakan, baik di Indonesia secara umum, maupun di tingkat lokal. Beberapa daerah kemudian mengeluarkan kebijakan yang berlandaskan syariat. Berdasarkan penelitian yang dilakukan oleh LIPI, dalam kurun waktu 19992014, muncul 443 perda syariah di Indonesia ${ }^{4}$. Seperti halnya Aceh, Sulawesi Selatan, Jawa Barat dan lainnya. Bisa saja jumlah itu bertambah saat ini. Kecenderungan itu semakin meningkat di tengah Indonesia menghadapi Pilkada 2017 dan Pemilu 2019 yang lalu.

Aceh juga menjadi bagian dari daerah yang punya kecenderungan dengan kebijakan yang berlandaskan agama, salah satunya zikir yang dilaksanakan oleh Pemerintah Kota Banda Aceh. Secara lebih detil, zikir dan programnya yang dianggarkan secara formal oleh Pemko Banda Aceh masuk ke dalam visi misi pertama walikota. Merujuk pada RPJMD Kota Banda Aceh, zikirmenjadi bagian dari misi 1 pemerintah Kota Banda Aceh dalam hal mewujudkan nilainilai Islami dalam seluruh aspek kehidupan warga Kota Banda Aceh, dengan sasaran yaitu meningkatkan kesadaran masyarakat dalam penerapan Syariat Islam Islam. Programprogram terkait zikir sudah tertuang dalam RPJM yang dieksekusi langsung oleh Dinas Syariat Islam sebagai pelaksana teknis. Ini seperti yang disampaikan Kepala Bidang Sumber Daya Manusia, Dinas Pendidikan Dayah Kota Banda Aceh, Bapak Syarifuddin:

... kalo ngak salah saya itu visi-misi pertama, di bidang syariat islam dan pendidikan dan itu zikir itu tertuang dalam RPJM dan itu ditangani oleh Dinas Syariat Islam, ..., karena beberapa pembahasan itu termasuk evaluasi RPJM saya hadir, dan itu ditanya bagaimana dampak zikir, dan itu orang DSI yang mampu menjawab terkait dengan perubahan sikap dan sebagainya (SY/8 Juli 2019).

4 https://www.bbc.com/indonesia/indonesia-49332135, diakses 20 September 2019.
Hal senada terkonfirmasi oleh pernyataan salah satu anggota dewan DPRK Banda Aceh: Kalau pengajuan program, pasti ini kan karena jadi visi misi beliau pasti beliau tuangkan dalam RPJM kan. Sebagai salah satu bagian dari eee.. penegakan syariat. Beliau terjemahkan dalam dzikir (IR/30 September 2019).

Menurut penjabaran RPJMD Kota Banda Aceh, beberapa tahun belakangan ini, penduduk Kota Banda Aceh diresahkan dengan muncul fenomena sosial diantaranya komunitas punk dan LGBT (Lesbian, Gay, Biseks dan Transjender) dan wanita tuna susila. Melihat fenomena tersebut, pemerintah Kota Banda Aceh menganggap bahwa adanya permasalahan penegakan peraturan terhadap maraknya kasuskasus yang meresahkan masyarakat tersebut. Selanjutnya masih dalam RPJMD Kota Banda Aceh, fenomena di atas menyebabkan pemerintah Kota Banda Aceh melakukan Syiar dan Dakwahmelalui zikir.Zikir dianggap sebagai usaha dan gerakan dakwah untuk menegakkan amar ma'ruf nahi mungkar. Permasalahan yang dihadapi terkait hal tersebut, maka isu strategis terkait bidang syariat Islam adalah sebagai berikut5:

a. Masih adanya pelanggaran terhadap Qanun Syariat Islam (Qanun Nomor 6 Tahun 2014 tentang Hukum Jinayah)

b. Belum optimalnya pelaksanaan syiar Islam c. Masih rendahnya variasi kegiatan remaja mesjid dan balai pengajian sehingga akhirnya membuat kevakuman.

Beberapa kutipan wawancara di atas menjelaskan bahwa elit tidak mengemukakan deskripsi kondisi yang ada di Kota Banda Aceh sehingga zikir merupakan salah satu kebijakan yang dapat mengatasi suatu persoalan. Selanjutnya elit politik di Kota Banda Aceh juga tidak menjelaskan bahwa hadirnya kebijakan zikir diakibatkan oleh terjadinya sekuritisasi keimanan yang sedang dialami oleh masyarakat di Kota Banda Aceh. Seperti yang ditambahkan oleh Pengelola Majelis Zikir Gemilang, yaitu:

Pendopo ini kan pusat pemerintah kota lah ya, rumah rakyat, rumah walikota, jadi kita ingin dari rumah inilah kita berdoa, mendekatkan diri pada Allah, mudah-mudahan Allah ta'ala berikan keberkahan kepada Kota Banda Aceh.

RPJMD Kota Banda Aceh tahun 2017-2022 
Pada intinya..., tidak terlalu ideal tapi paling tidak kita ingin dirumahnya pimpinan rakyat ini terlaksana. (JS, 11 Juli 2019).

Lebih lanjut, kebijakan zikir menjadi pertimbangan kebijakan populis yang dapat membentukfigurpolitisiterpilih. Karena program yang mengarah ke agama dapat membentuk citra politisi, apalagi zikir menjadi kebijakan yang populer saat ini. Seperti dikemukakan oleh pembina majelis Zikir Geumilang berikut ini:

Waktu itu memang lagi ini lagi famous zikir, misalnya ada Ust. Samunzir dengan Majelis Zikrullah Aceh, dan majelis zikir lain, sehingga memang masyarakat sangat menerima zikir maka dibuatlah zikir sebagai sebuah program oleh Pemko Banda Aceh yang masuk dalam salah satu misinya. (JR/11 Juli 2019).

Pemaparan di atas menjelaksan bahwa menjadi simbol keimanan bukan menjadi bagian dari sekuiritisasi iman. Karena hanya menyentuh simbolis maka ia menjadi kebijakan populer yang belum tentu menyentuh hal substansi. Kebijakan populer untuk membentuk karisma atau figur politisi.

\section{2) ZikirSebagai Wujud Pemenuhan Komitmen Kampanye Politik dan Kompensasi Politik}

Zikir menjadi salah satu program unggulan yang ditawarkan oleh kandidat (Aminullah Usman dan Zainal Arifin) pada Pilkada 2017. Ia menjadi "produk jualan" untuk menandingi popularitas petahana dalam Pilkada 2017. Petahana (Illiza Sa'aduddin Djamal) yang merupakan wakil walikota periode 20062012 dan walikota 2012-2017. Ketika beliau memimpin, beliau sangat fokus dengan penegakan syariat Islam dalam bentuk penindakan tegas bagi pelanggar syariat Islam, baik hukum cambuk bagi pelanggar, razia tempat hiburan seperti cafe dan karaoke, razia pakaian di jalan dan lain sebagainya.

Beberapa masyarakat merasa terganggu dengan hal itu, maka Aminullah sebagai penantang melakukan cara yang berbeda dengan fokus pada pelaksanaan syariat islam dengan upaya pencegahan bukan penindakan seperti yang dilakukan oleh petahana. Berikut keterangan dari tim sukses Aminullah Usman: Salah satu analisa yang paling tepat menurut kita dan membuat kita menang adalah Ibu Illiza tidak melaksanakan syariat Islam secara substanstif. Beliau lebih ke patroli $\mathrm{WH}$, menangkap orang dan sebagainya....kami lebih ke tausiah melalui zikir. (RJ/ Juli 2019)

Strategi tersebut akan meningkatkan popularitas Aminullah Usman. Menurut salah satu dinas di Kota BandaAceh, zikir menjadi program utama Walikota terpilih sejak kampanye: Zikir ya zikir akbar ini merupakan program utama dari pada pemerintah kota Banda Aceh itu, karena itu juga merupakan janji wali kota pada saat kampanye hehe, tapi kita ngak bisa kita bilang lagi, memang ini sudah yang utama, yang laen ngak ada, yang ini harus ada.(IS/10 Juli 2019).

Masih berkaitan dengan Pilkada, zikir merupakan kompensasi politik walikota terpilih dengan jaringan pendukungnya. Kelompok organisasi Islam yang mendukung Walikota terpilih ketika kampanye sudah membuat janji politik, bahwa dukungan akan diberikan dengan janji akan membuat zikir sebagai salah satu program Pemerintah Kota Banda Aceh bila ia terpilih. Seperti penjelasan Ustad SJ berikut: saya dengan Pak Amin kan, kami kan partner karena saya dulu juga pernah calon juga waktu itu. Saya tidak jadi calon karena dukungan KTP saya yang tidak memenuhi persyaratan...maka saya dan tim mendukung Pak Aminullah. (SJ/11 Juli 2019).

\section{3) Sarana Komunikasi Publik dan Klarifikasi Kebijakan Walikota}

Zikir, dalam pelaksanaannya menggunakan pendopo walikota sebagai fasilitas. Hal itu adalah salah satu cara menjadikan pendopo sebagai sebuah ruang yang dapat diakses oleh publik dengan mudah. Seperti penjelasan dari tim Walikota: Zikir adalah salah satu kebijakan. ada satu kebijakan gini pertama kita tidak mau mengeksklusifkan pendopo, tidak mau hanya orang-orang tertentu yang hanya bisa mengakses pendopo, caranya adalah kita buat kegiatan yang bermanfaat yang bisa dirasakan oleh banyak orang terkait dengan visi dan misi kita. ... jadi kita harus gemarkan zikir ... caranya mulai dari pendopo. (RJ/4 Juli 2019).

Ketika zikir dapat diakses publik, zikir juga merupakan wadah komunikasi dan klarifikasi kebijakan publik Walikota. Program zikir yang dilaksanakan oleh Pemerintah Kota Banda Aceh dijadikan oleh elit untuk memfasilitasi komunikasi langsung dengan masyarakat (selain car free day yang dilaksanakan setiap hari Minggu dan momen -momen lainnya): 
Jadi saya lihat momen zikir ini diantara salah satu pintu masyarakat untuk mengadu keluhan kepada Pak Wali walaupun tidak diformal kan, kan gak dibuat seperti acara formal malam ini ada acara selanjutnya apa namanya curhat masyarakat, tidak tapi masyarakat dengan sendirinya kalau memang ada keluhan, ada uneguneg mereka akan sampaikan dengan moment seperti ini. (SJ/11 Juli 2019).

Walaupun untuk komunikasi langsung dan menyerap aspirasi, belum tentu kemudian memberikan solusi langsung bagi permasalahan tersebut. Minimal kegiatan zikir ini dapat menjadi wadah untuk bertemu langsung dengan masyarakat dan melakukan konfirmasi atas kebijakan dan perihal yang terjadi di Kota Banda Aceh. Kemudian zikir juga pola mobilisasi untuk membangun jaringan dan dukungan. Seperti penjelasan pengelola majelis zikir gemilang berikut: Zikirkan berkelompok-kelompok. Zikir jadi secara signifikan mempengaruhi kelompokkelompok masyarakat yang sangat berpengaruh bagi masyarakat, ya kelompok zikir ini adalah kelompok-kelompok berpengaruh, kelompok -kelompok yang punya power di masyarakat, dengan adanya zikir ini di pendopo atau dimana-mana sehingga menggerakkan komunitas-komunitas tertentu untuk mendukung syariat islam, jadi sangat realistis, sangat strategis, karena dia bukan hanya sekedar zikir, tapi ada membangun jaringan.

Dalam kegiatan zikir, selain masyarakat dan SKPK yang hadir, juga hadir beberapa kelompok keagamanan dan organisasi keagamaan di Kota Banda Aceh. Kemudian dalam kegiatan zikir tersebut, selain berzikir, kegiatan diawali dengan kata sambutan dari Walikota atau Wakil Walikota. Pada kesempatan tersebut Walikota atau Wakil Walikota menjelaskan atau mengkonfirmasi kondisi yang sedang terjadi di Kota Banda Aceh, seperti permasalahan air bersih, sampah atau hal-hal yang ramai diperbincangkan oleh masyarakat. Dengan demikian ketiga perihal di atas menjadi wacana kebijakan zikir sebagai model kebijakan populis yang dilaksanakan oleh Pemerintah Kota Banda Aceh.

Dimensi politik menjelaskan bagaimana elit membutuhkan media untuk menframing dan mengklarifikasi tentang dirinya dan kinerja pemerintahan sesama mereka. Terlihat masih terdapat beberapa persoalan pelayanan dasar masyarakat Kota Banda Aceh yang belum terselesaikan dalam dua tahun terakhir. Pertama, masalah pelayanan air bersih, kedua energi listrik di Kota Banda Aceh, dan ketiga pengelolaan kebersihan dan Sampah belum juga terwujud. Dengan demikian, zikir rutin cukup efektif menjadi media bagi elit, dimana elit menggunakan media zikir untuk mempertahankan elektabilitas dengan klarifikasi publik yang dilakukan secara rutin.

Dari sisi pilihan publik, dimensi wacana politik, integrasi motivasi elit antara homo economicus dan homo politicus belum terlihat. Namun yang jelas, sebagaimana yang dijelaskan Botti dan Iyengar (2006), bahwa politisi mengkapitalisasi kepentingan pribadi dan kelompok dalam pasar politik. Sementara dalam analisa wacana politik kritis, penggunaan isu agama, seperti zikir, sebagai bagian dari upaya meningkatkan elektabitalitas dan popularitas merupakan representasi dari prilaku elit politik sebagai aktor sosial (Van Leeuwen, 2013).

Bahkan, isu sekuritisasi keimanan dalam bingkai (framing) atas nama publik, bisa muncul menjadi fokus ditengah elit politik yang bertarung mempertahankan kepemimpinannya atau memenangkan proses pemilihan, khususnya dalam masyarakat yang lama berkutat dalam perang saudara, seperti di Bosnia (Hansen, 2013). Jika analisis Hansen benar, maka yang terjadi di Aceh, kurang lebih hampir sama, isu agama seringkali dipakai menjadi isu sekuritisasi iman dalam konteks politik di ranah kebijakan publik.

\section{SIMPULAN}

Penelitian ini dapat menjelaskan zikir menjadi sebuah pilihan rasional ditengah kondisi masyarakat. Tidak maksimalnya peran pemerintah dalam mensejahterakan, maka penting ada media bagi elit untuk mendekatkan dan mempengaruhi dukungan publik. Dalam relevansinya dengan logika pilihan rasional populis dalam sebuah kebijakan, walaupun belum menjadi instrumen komprehensif penyelesaian masalah publik di Kota Banda Aceh, wacana kebijakan "atas nama publik" sudah menjadi fenomena yang lazim digunakan. Padahal kepala daerah terpilih menjadikan zikir sebagai salah satu prioritas pembangunan dalam masa kepemimpinannya. Kegiatan zikir diharapkan bisa menyelesaikan akar dari permasalahan 
sosial ekonomi dan bisa dilihat dampaknya dalam jangka waktu tertentu. Dengan demikian cukup penting bagi zikir sebagai sebuah kebijakan untuk tidak terkungkung dalam imajinasi wacana politik dan menjadi konstruksi wacana di media dalam bingkai populisme elit. sehingga tidak atau belum memberikan signifikansi dampak ke masyarakat luas sebagai end user. Namun penting untuk menerjemahkan zikir sebagai sebuah kebijakan kedalam hal yang lebih konkrit dan program berorientasikan kesejahteraan publik.

\section{UCAPAN TERIMA KASIH}

Ucapan terimakasih setinggi-tingginya kami sampaikan kepada Pusat Penelitian Universitas Islam Negeri Ar-Raniry Banda Aceh yang telah mendukung terlaksananya penelitian ini melalui alokasi DIPA Tahun 2019 Universitas Islam Negeri Ar-Raniry pada kategori Penelitian Dasar Interdisipliner.

\section{DAFTAR PUSTAKA}

Benington, J. (2011). From private choice to public value. Public value: Theory and practice, 31-49.

Creswell, J. W. Research design: Qualitative and mixed methods approaches. London and Thousand Oaks: Sage Publications, 2009.

Dye, T. R. Understanding public policy. Pearson: Canada, 2011.

Faber, S. (2018). Is Dutch Bad Boy Thierry Baudet the New Face of the European AltRight?. The Nation, 5.

Flick, U. (2018). An introduction to qualitative research. Sage Publications Limited.

Hansen, L. (2013). Security as practice: discourse analysis and the Bosnian war. Routledge.

Huberman, M., \& Miles, M. B. The qualitative researcher's companion. Sage, 2002.

Kropf, R. W. (2003). Faith: Security and Risk: The Dynamics of Spiritual Growth. Wipf and Stock Publishers.

Lathrop, D. A. (2003). The campaign continues: How political consultants and campaign tactics affect public policy. ABC-CLIO.
Lofland, L. (1999). A World of Strangers: Order and action in urban public space. New York: Basic Books.

Mason, J. Qualitative Researching. London: SAGE Publications, 2002.

Maulana, P. Zikir Akbar (Analisis terhadap Program Dakwah di Mesjid Raya Baiturahman Banda Aceh) (Doctoral dissertation, UIN Ar-Raniry Banda Aceh), (2017).

Mudde, C., \& Kaltwasser, C. R. Populism: A very short introduction. Oxford University Press, 2017

Silverman, D. (Ed.). Qualitative research. Sage, 2016.

Tracy, S. J. Qualitative research methods: Collecting evidence, crafting analysis, communicating impact. John Wiley \& Sons, 2019.

Vagle, M. D. (2018). Crafting phenomenological research. Routledge.

Van Leeuwen, T. (2013). The representation Of social actors. In Texts and practices (pp. 4179). Routledge.

Wilson, E. K. (2012). After secularism: Rethinking religion in global politics. Palgrave Macmillan.

Mietzner, M. Reinventing Asian populism: Jokowi's rise, democracy, and political contestation in Indonesia. Honolulu, HI: East-West Center, 2015.

Acemoglu, D., Egorov, G., \& Sonin, K. “A political theory of populism." The Quarterly Journal of Economics, 128(2) (2013): 771-805.

Ádám, Z. (2019). Explaining orbán: A political transaction cost theory of authoritarian populism. Problems of Post-Communism, 66(6), 385-401.

Albertazzi, D., Giovannini, A., \& Seddone, A. (2018). 'No regionalism please, we are Leghisti!'The transformation of the Italian Lega Nord under the leadership of Matteo Salvini. Regional \& Federal Studies, 28(5), 645-671.

Ardiyaningrum, M. "Religiusitas Gaya Baru (Kajian Atas Fenomena Kebangkitan Sufisme Kelas Menengah Perkotaan Di 
Yogyakarta).” Dialogia: Jurnal Studi Islam dan Sosial, 15(2) (2017), 221-242

Aspinall, E. (2015). Oligarchic populism: Prabowo Subianto's challenge to Indonesian democracy. Indonesia, (99), $1-28$.

Astalin, P. K. (2013). Qualitative research designs: A conceptual framework. International Journal of Social Science and Interdisciplinary Research, 2(1), 118-124.

Botti, S., \& Iyengar, S. S. (2006). The dark side of choice: When choice impairs social welfare. Journal of Public Policy \& Marketing, 25(1), 24-38.

Chevigny, P. The populism of fear: Politics of crime in the Americas. Punishment \& Society, 5(1) (2003): 77-96.

Chilton, P. (2017). "The people" in populist discourse: Usingneuro-cognitive linguistics to understand political meanings. Journal of Language and Politics, 16(4), 582-594.

Etikan, I., Musa, S. A., \& Alkassim, R. S. "Comparison of convenience sampling and purposive sampling." American journal of theoretical and applied statistics, 5(1) (2016):1-4.

Fairclough, N. (2013). Critical discourse analysisand critical policy studies. Critical policy studies, 7(2), 177-197.

Feighery, W. G. (2012). Tourism and self Orientalism in Oman: a critical discourse analysis. Critical Discourse Studies, 9(3), 269-284.

Fennema, M. (2005). Populist parties of the right. Movements of exclusion: Radical rightwing populism in the Western world, 1-24

Fikri, S. Strategi Tarekat Dalam Menyebarkan Dakwah di Nusantara. Jurnal Hikmah, 8(2) (2014). 99-113.

Fontana, A., \& Frey, J. H. (2000). The interview: From structured questions to negotiated text. Handbook of qualitative research, 2(6), 645-672.

Franzmann, S. T. (2016). Calling the ghost of populism: The AfD's strategic and tactical agendas until the EP election 2014. German Politics, 25(4), 457-479
Gregory, R. (2014). Assessing 'Good Governance': 'scientific' measurement nd political discourse. Policy Quarterly, 10(1).

Guest, G., MacQueen, K. M., \& Namey, E. E. (2012). "Introduction to applied thematic analysis." Applied thematic analysis (2012), 3, 20.

Hadiz, V. R. (2018). Imagine all the people? Mobilising Islamic populism for rightwing politics in Indonesia. Journal of Contemporary Asia, 48(4), 566-583.

Hanley, S. (2004). Getting the right right: redefining the centre-right in postcommunist Europe. Journal of Communist Studies and Transition Politics, 20(3), 9-27.

Hasan, N. (2012). Piety, Politics, and PostIslamism: Dhikr Akbar in Indonesia. AlJami'ah: Journal of Islamic Studies, 50(2), 369-390

Hawkins, K. (2003). Populism in Venezuela: the rise of Chavismo. Third World Quarterly, 24(6), 1137-1160

Holburn, G. L., \& Bergh, R. V. (2002). Policy and process: A game-theoretic framework for the design of non-market strategy. Advances in strategic management, 19, 3366.

Iqbal, M. M. (2014). Dinamika Wacana Formalisasi Syariat Dalam Politik: Ikhtiar Menemukan Relevansi Relasi Agama Dan Negara Perspektif Indonesia. Walisongo: Jurnal Penelitian Sosial Keagamaan, 22(1), 83-104.

Ivarsflaten, E. (2008). What unites rightwing populists in Western Europe? Reexamining grievance mobilization models in seven successful cases. Comparative Political Studies, 41(1), 3-23.

Jatmiko, M. I. (2019). Post-Truth, Media Sosial,Dan Misinformasi: Pergolakan Wacana Politik Pemilihan Presiden Indonesia Tahun 2019. Jurnal Dakwah Tabligh, 20(1), 21-39.

King, R. G., \& Rebelo, S. (1990). Public policy and economic growth: developing neoclassical implications. Journal of political Economy, 98(5, Part 2), S126-S150. 
Knight, A. (1998). "Populism and neo populism in Latin America, especially Mexico." Journal of Latin American Studies, 30(2) (1998): 223-248.

Mardiyanta, A. (2011). Kebijakan Publik Deliberatif: Relevansi dan Tantangan Implementasinya. Masyarakat, kebudayaan Dan Politik, 24(3), 261-271.

Montgomery, M. (2017). Post-truth politics?: Authenticity, populism and the electoral discourses of Donald Trump. Journal of Language and Politics, 16(4), 619-639.

Neveu, N. (2010). Islamic tourism as an ideological construction: A Jordan study case. Journal of Tourism and Cultural Change, 8(4), 327-337.

Nisma, Y. (2019). Rateb Siribee: Spiritualitas Dan Solidaritas Religius Masyarakat Pedesaan Di Aceh Modern. Jurnal Sosiologi Agama Indonesia (JSAI), 1(2), 1-20.

Pierson, P. (2017). American hybrid: Donald Trump and the strange merger of populism and plutocracy. The British journal of sociology, 68, S105-S119.

Ruzza, C., \& Balbo, L. (2013). Italian populism and the trajectories of two leaders: Silvio Berlusconi and Umberto Bossi. Right-wing populism in Europe: Politics and discourse, 163-176.

Shadiqin, S. I. (2018). Tasawuf di Era Syariat: Tipologi Adaptasi dan Transformasi Gerakan Tarekat dalam Masyarakat Aceh Kontemporer. SUBSTANTIA, 20(1), 6679

Stockemer, D., \& Barisione, M. (2017). The 'new'discourse of the Front National under Marine Le Pen: A slight change with a big impact. European Journal of Communication, 32(2), 100-115.

Syamaun, S. (2019). Komunikasi Sinergistik Pemerintah Kota Banda Aceh Dan Majelis Pengajian Tauhid Tasauf Dalam Mewujudkan Masyarakat Seimbang. Jurnal Peurawi, 2(1), 1-20.

Wodak, R. (2008). Us' and 'them': Inclusion and exclusion-Discrimination via discourse. Identity, belonging and migration, 54-77.
Zamhari, A. (2007). Rituals of Islamic spirituality: a study of Majlis Dhikr (Vol. 60, No. 3, pp. 701-729). by ANU E Press.

Admin Nba.(12 September2018). WujudkanKota Zikir, Wakil Wali Kota: Kami Sangat Berharap Doa Dari Kita Semua. News Banda Aceh. Diakses, https://www. newsbandaaceh.com/2017/11/wujudkankota-zikir-wakil-wali-kota-kami-sangatberharap-doa-dari-kita-semua/

Dwiastono, R. (15 Agustus 2019). Perda Syariah di Indonesia: antara Keariffan Lokal, Politik Elektoral dan Ancaman terhadap kebhinekaan, BBC Indonesia, 20 September 2019. Diakses dari https://www. bbc.com/indonesia/indonesia-49332135

Junaidi, H. (28 April 2018), Selalu Dipenuhi Jemaah Zikir: Aminullah: Saya Sangat Bahagia, Diakses dari https:// bandaacehkota.go.id/berita/9483/pendoposelalu-dipenuhi-jemaah-zikir-aminullahsaya-sangat-bahagia.html

Yulianto, A. (12 September 2018). Semarak Zikir 1 Muharram di Serambi Makkah. Republika. Diakses dari https://www. republika.co.id/berita/dunia-islam/islamnusantara/17/09/20/owk1ly396-semarakzikir-akbar-1-muharram-di-serambimakkah

Masrizal. (2017, Januari 29). Kampanye Akbar Illiza-Farid akan Diisi dengan Zikir dan Tausiah. Serambi News. Diakses dari https://aceh.tribunnews.com/2017/01/29/ kampanye-akbar-illiza-farid-akan-diisidengan-zikir-dan-tausiah

Leifeld, P. (2010, March). Political Discourse Networks-The missing link in the study ofpolicy-oriented discourse. In workshop" Ideas,Policy Design and Policy Instruments: Castingthe Missing Link", ECPR Joint SessionsMünster, March 2227.

Jumlah Wisatawan Kota Banda Aceh 20182019, Open Data Kota Banda Aceh. diakses 10 Desember 2019 dari: https:// data.bandaacehkota.go.id/index.php/ dataset/single/jumlah-wisatawan-kotabanda-aceh/109cc537-6c6b-4c08-a289ee9dfd395842, 